\title{
The Place of Effective Planning and Organizational Resource in Manufacturing Firms in Perspective
}

DOI: https://doi.org/10.47175/rissj.v1i2.47

\section{| Anthony Anyibuofu Kifordu ${ }^{1}$ | Asunday Ogala ${ }^{2}$ |}

${ }^{1}$ Department of Business

Administration and Marketing, Faculty of Management Sciences Delta State University Asaba Campus, Delta State, Nigeria

${ }^{2}$ Department of Arts and Humanities

School of General Studies

Delta State Polytechnic

Ogwashi- Uku

Delta State

${ }^{1}$ anthony.kifordu@yahoo.com

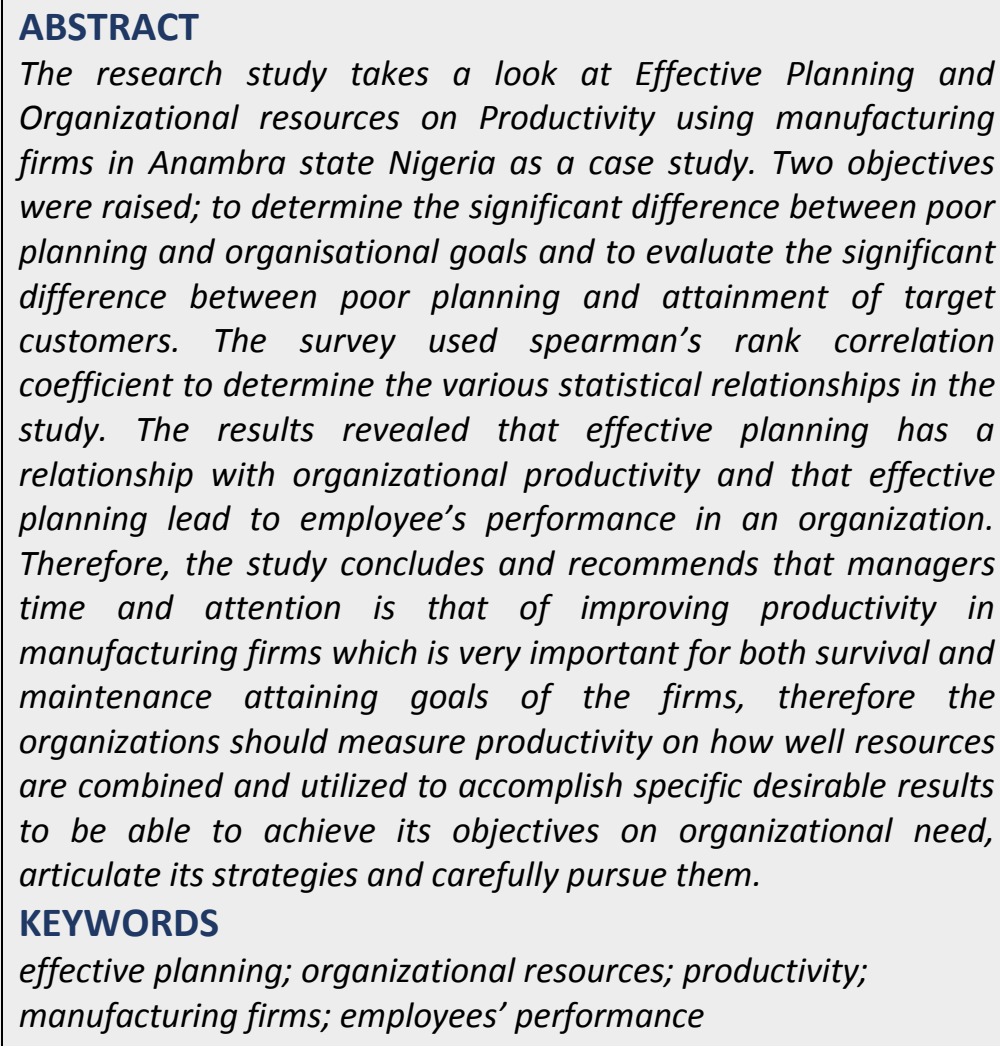

\section{INTRODUCTION}

In majority of firms in Nigeria, planning is the most important management tool for performance and for organizations to perform well. Planning is the basic function of management, it also deals with forecasting the future course of action and deciding in advance the most appropriate course of action for achievements of pre - determined goals. According to Theo Haimann, "Planning is deciding in advance what is to be done. When a manager plans, he projects a course of action for further attempting to achieve a consistent co-ordinate structure of operations aimed at the desired results". Planning can be seen in two different angles. First, as a function or responsibility of every manager who has people under him working towards the achievement of desired organizational goals. That means looking ahead and chalking out future courses of action to be followed. It is a preparatory step.

It is a systematic activity which determines when, how and who is going to perform a specific job. Planning is a detailed programme regarding future courses of action. Secondly planning is among the primary function of management. It is required practically at all levels of management. Organizational resources are all assets that a corporation has available to use in the production process namely human resources, capital resources, monetary resources, and raw material (ebook). The proper utilization of these resources bring about the increase in productivity i.e efficiency in business. Taking it back to the definition above planning, management and business are very necessary to note when 
establishing an environment for effective performance of persons. Essentially, planning is concerned with the management of human resources of an organization in contest to the material or financial resources which is meant to foster effectiveness in the collective use of human talents for the overall benefit and interest of the employee and the organization.

The success of human resource planning process not only helps the organization itself, but also helps the society prosperity. The losses a firm suffers from inadequate human resource planning and utilization is a loss to the nation. When these individuals losses are added up, the total loses may be very significant to the economy. Productivity is essential to the success of any organization. According to Ray Wild "Production Planning is concerned with the determination, acquisition and arrangement of all facilities necessary for future operations". The affirmative purpose is to increase the degree of organizational success. Productivity through planning in the business helps to create market, maximize profits and create good will for the organization. It is accomplished through analysis of internal factors such as current and old data's Environmental factor such as the labour requires competent people with appropriate skills that are available to perform jobs where and when they will be needed. According to Antoine de Saint- A good goal without a plan is just a wish - so start planning" A plan is only as good as those who see it through.

Planning is a very necessary and useful function of management. It requires high level of performance and also helps the management to identify future opportunities and also ensure that all the subordinates are working towards the same goals, without effective planning the desired goals will not be achieved. There is no formed systemic planning and utilization of resources in most organisation which has resulted to inefficiency and decrease in productivity, effective planning of human resources, capital, monetary resources, and raw materials brings about increase in productivity which leads to increase in productivity which leads to increase in profit.

A good management of people and organizational resources is important to the success of any organisation. One of the top and fatal consequence of poor planning in an organization is business failure. This results is something that should be avoided at all costs. Areas mostly affected due to poor planning i.e over budgeting, poor quality customer dissatisfaction, over-extension of project deadlines, miscommunication between team employees and managers, lack of clarity on project objectives and low team morale. Planning is the foundation on which organisations base business execution. Without a strong and stable foundation, the business is more likely to collapse. Good planning will ensure that the resources are ideally utilised. The organization should not waste resources when planning a project as this will result in the decrease of the overall profit from the project. The whole team should work as a unit to complete the task. Improper planning will result in the assignment of redundant tasks, thus increasing the cost and time taken to complete the project.

There are many theories that supports the motion of this study but this work would focus on Maslows theory under organisation behaviour. This hierarchy suggests that people are motivated to fulfill basic needs before moving on to other, more advanced needs. While some of the existing schools of thought at the time (such as psychoanalysis and behaviorism) tended to focus on problematic behaviors, Maslow was much more interested in learning about what makes people happy and the things that they do to achieve that aim.

As a humanist, Maslow believed that people have an inborn desire to be self-actualized, that is, to be all they can be. In order to achieve these ultimate goals, however, a number of more basic needs must be met such as the need for food, safety, love, and self-esteem 
The application of effective planning is to Abraham Maslow's Hierarchy of Needs Theory of motivation helps to develop an organization that meets employee needs through human resource management while encouraging increased levels of performance yielding to productivity. The theory offers a basis for organizational development to plan with high employee motivation to achieve company objectives. An organization that satisfies Maslow's principles can feature high employee satisfaction, excellent employee retention and cohesive teams

\section{RESEARCH METHODS}

A survey design. The population is 2141 comprising of organizations listed by the industrial directory of the ministry of commerce and industry, Anambra State. The industrial directory obtained from Anambea state ministry of commerce and industry contained many different organisations grouped into their various local government areas under their senatorial districts. It was therefore necessary to select a sampling technique and a sample. In the first instance, one hundred and twenty five (125) organisations were arbitrarily selected from Anambra state Industrial directory. The one hundred and twenty five (125) organisations, constituted of organisations selected from two local government areas: Anambra East and Anambra North local government areas of Anambra state with a total of one hundred and twenty five (125) organisations. Anambra east had fifty (50) organisations and Anambra west had seventy (70) organisations respectively.

These two local government areas were picked by the lottery method were we started by contracting a sample frame. This was a comprehensive list of all the members of the population of interest. Each member was assigned a number and entered separately on equal size paper. The papers were folded to equal size and places in a basket and rotated. A neutral person was called upon to pick the paper from the basket. This drawing process was repeated until the sample size was obtained. Chi square was used for analysis as measure of discrepancy which exist between the observed frequency and expected frequency, if the difference between the expected frequency and and observed frequency is less than the level of significance desired, we accept the Null hypothesis otherwise, we accept alternative hypothesis

\section{RESULT AND DISCUSSION}

\section{Hypothesis One}

Questions 1, 4, 15, 16 and 17 were designed to test hypothesis one that states that Is there significant difference between poor planning and organisational goals.

The Chi-square was applied as shown in Table 2 using Table 1 grouping and Table 4 is the chi-square analysis for hypothesis one

Table 1. Coding sheet result

\begin{tabular}{cccccc}
\hline Question No & $\begin{array}{c}\text { Strongly } \\
\text { agreed }\end{array}$ & Agreed & Uncertain & Disagreed & $\begin{array}{c}\text { Strongly } \\
\text { Disagreed }\end{array}$ \\
\hline 1 & - & 50 & 40 & - & - \\
2 & 20 & 20 & 10 & 60 & 40 \\
3 & 30 & 40 & 5 & - & 75 \\
4 & 30 & 35 & 5 & 10 & 70 \\
5 & 30 & 30 & 10 & 20 & 60 \\
6 & 70 & 30 & 10 & 20 & 20 \\
7 & 40 & 25 & 5 & 70 & 10 \\
8 & 23 & 20 & 7 & 80 & 20 \\
9 & 20 & 42 & 8 & 70 & 10 \\
\hline
\end{tabular}




\begin{tabular}{cccccc}
\hline 10 & 75 & 10 & 3 & 40 & 23 \\
11 & 25 & 20 & 15 & 50 & 40 \\
12 & 80 & 25 & 5 & 20 & 20 \\
13 & 15 & 25 & - & 80 & 30 \\
14 & 12 & 8 & 15 & 20 & 95 \\
15 & 70 & 35 & 7 & 15 & 23 \\
16 & 60 & 30 & 10 & 30 & 20 \\
17 & 30 & 3 & 12 & 75 & 30 \\
18 & 60 & 26 & 9 & 30 & 25 \\
19 & 70 & 35 & 4 & 20 & 21 \\
20 & 75 & 25 & 10 & 20 & 20 \\
21 & 65 & 30 & 3 & 22 & 30 \\
22 & 80 & 35 & 2 & 20 & 13 \\
23 & 60 & 45 & 25 & 13 & 17 \\
24 & 55 & 25 & - & 20 & 50 \\
25 & 76 & 40 & 13 & 12 & 9 \\
26 & - & 80 & 20 & 20 & 20 \\
27 & 40 & 70 & 25 & 8 & 7 \\
28 & 60 & 30 & 20 & 20 & 20 \\
29 & 45 & 70 & 10 & 10 & 15 \\
30 & 30 & 50 & 5 & 5 & 60 \\
31 & 25 & 60 & 3 & 7 & 55 \\
32 & 40 & 75 & - & 20 & 15 \\
\hline
\end{tabular}

Table 2. Grouping to analyze hypothesis one

\begin{tabular}{lcccccc}
\hline Question No & $\mathbf{1}$ & $\mathbf{4}$ & $\mathbf{1 5}$ & $\mathbf{1 6}$ & $\mathbf{1 7}$ & Total \\
\hline Yes & 50 & 65 & 105 & 90 & 33 & 310 \\
No & 60 & 80 & 38 & 50 & 105 & 333 \\
Total & 110 & 145 & 143 & 140 & 138 & 676 \\
\hline
\end{tabular}

Remarks: Calculated chi-value is far greater than the table value at alpha (confidence) level of 0.05 and degree of freedom 4. The null hypothesis that there is no significant difference between poor planning and organisational therefore rejected.

Table 3. Chi-square analysis

\begin{tabular}{llrcc}
\hline fo & fe & fo-fe & (fo-fe)/ 2 & (fo-fe)2/fe \\
\hline 50 & 50 & 0 & 0 & \\
65 & 66 & -1 & 1 & 0.02 \\
105 & 66 & 39 & 521 & 14.5 \\
90 & 64 & 26 & 676 & 7.5 \\
33 & 63 & -30 & 900 & 27.3 \\
60 & 34 & 6 & 36 & 0.6 \\
80 & 71 & 9 & 81 & 2.0 \\
38 & 70 & 32 & 1024 & 27.0 \\
50 & 68 & -18 & 24 & 6.5 \\
105 & 68 & 57 & 369 & 13.0 \\
\hline
\end{tabular}

\section{Hypothesis Two}

Questions 1,5,7,9 and 11 on the questionnaire were designed to test this hypothesis which states that is there any significant difference between poor planning and attainment of target customers? 
Table 4 is a summary of the grouping of the questions and Table 5 is the Chi- square analysis.

Table 4. Grouping for hypothesis two test

\begin{tabular}{lllllll}
\hline Question No & $\mathbf{1}$ & $\mathbf{5}$ & $\mathbf{7}$ & $\mathbf{9}$ & $\mathbf{1 1}$ & Total \\
\hline Yes & 50 & 60 & 65 & 62 & 45 & 282 \\
No & 60 & 80 & 80 & 80 & 90 & 390 \\
Total & 110 & 140 & 145 & 142 & 135 & 672 \\
\hline
\end{tabular}

Source: Field Analysis, 2020

Table 5. Chi-square analysis for hypothesis two

\begin{tabular}{rrrrc}
\hline fo & fe & fo-fe & (fo-fe) $^{\mathbf{2}}$ & (fo-fe)2/fe \\
\hline 50 & 64 & -14 & 196 & 3.9 \\
60 & 58 & 1 & 1 & 0.02 \\
65 & 61 & 4 & 16 & 0.25 \\
62 & 60 & 2 & 4 & 0.07 \\
45 & 57 & 12 & 144 & 3.2 \\
60 & 64 & 4 & 16 & 0.27 \\
80 & 81 & -1 & 1 & 0.01 \\
80 & 84 & -4 & 16 & 0.02 \\
80 & 82 & -2 & 4 & 0.05 \\
90 & 78 & 12 & 144 & 1.6 \\
\hline \multicolumn{5}{c}{ Chi-value was 9.57 and the table value is 9.49. }
\end{tabular}

Remarks: Since the calculated value is approximately the same as the table value at alpha level 0.05 and degree of freedom 4, the null hypothesis states that there is no significant difference between poor planning and attainment of target customers. Therefore is rejected

This paper has examined effective planning on organizational resources on productivity. The major constraints in the successful attainment of remarkable organizational output have been the inability to properly plan before embarking on production. Planning also should be integrated with budgeting and capital should be made available from the onset. If the suggested approaches are imbibed, enhanced productivity with its attendant positive development of the organizational operations will be achieved by most manufacturing firms in Amambra state.

\section{CONCLUSION}

Conclusion on the key issues that manager's time and attention is that of improving productivity which is very important for both survival and maintenance of profit margins. Productivity is a measure of how well resources are combined and utilized to accomplish specific desirable results to be able to achieve its objectives on organization need articulate its strategies and carefully pursue them. There is no gain saying therefore that the success or otherwise of any organization depends on how effective their plans are.

The manufacturing industry offers intangible products, hence its efficiency and effectiveness can only be measured in terms of how well its service are delivered to its various publics. In recent years, the banking sector has witnessed tremendous growth. In fact, the sector is said to be the most active within the economy.

\section{REFERENCES}

Alford, L.P., and Beatty, H.R., (2000). Principles of Industrial Management.

Bernolak P (1997). Production and organizational growth. International Journal of Production Economics. 
B.M. Nnadozie and E.O. Akuezuilo. (1995). Education: Social and Management Science Journal. Publisher; Heineman.

Dickenson J.P. (1996). Statistic for Business Finance and Accounting Mc Donald and Evans Limited. Plymouth.

Geotz, N. (1999). Management and Planning, a propeller for organizational performance. Journal of College of Management Goteburg University. Plymouth Macdonald and Even Publication limited. http://www.businessdictionary.com/definition/humanresources

Koontz, H. O'Donnell, C and Weibrich, H .(1980). Management in broad perspective, Management of Multidisciplinary study. Tokyo Macgraw Hill Publication limited.

Lapin I.L. (1993). Statistic for Modern Business Decisions. New York, The Harbrace Series in Business and Economics.

Nzelibe C.G.O. and Ilogu C.C (1996). Fundamentals of Research Method. Enugu Publisher.

Stoner, J (1982). Management and Planning, a broader perspective, a textbook. Prentice Hall Publication limited.

R. Spigel Mumy (1992). Theory and Problem of Statistics. New York. Mcgraw Hill Book Company. Pp. 246 